Pregledni članak UDK: 165.71(045) Grlić, D.

doi: $10.21464 /$ fi41308

Primljeno 17. 10. 2019.

\title{
Slađana Kavarić Mandić
}

Goričani bb, Golubovci, ME-81000 Podgorica

kavaric.sladjana@gmail.com

\section{Dogma i stvaralaštvo: prilog vrednovanju Grlićeve kritike dogmatizma}

\begin{abstract}
Sažetak izvornog marksizma.

Ključne riječi

Danko Grlić, Karl Marx, marksizam, dogma, stvaralaštvo, humanizam
\end{abstract}

Rad se bavi temeljnim karakteristikama dogmatskog mišljenja, posebno imajući u vidu odnos prema stvaralačkoj biti čovjeka. Problematizirajući razvoj čovjeka i njegove (samo) percepcije u uvjetima poželjne jednoznačnosti i limitirane slobode, rad ukazuje na neophodnost stalnog prevladavanja danih mogućnosti, te značaj slobodarskih, antidogmatskih praksi u cilju ozbiljenja humanističke filozofije. Referirajući na temeljne pretpostavke filozofije Danka Grlića, rad ispituje konsekvence političke instrumentizacije Marxa, upozorava na jednodimenzionalnost dogmatskog mišljenja i naglašava antidogmatsku prirodu

\section{Uvod}

Da bi se što objektivnije sagledao odnos dogme i stvaralačkog u Grlićevu mišljenju, ali i priroda njihove temeljne suprotstavljenosti, čini se neophodnim ponajprije ukazati ne samo na konsekvence dogmatskog tumačenja Marxa, dakle, ne samo skrenuti pozornost na ono što posredstvom jednoobrazne i iskrivljujuće interpretacije marksizam gubi nego i podsjetiti na to koliko je antidogmatizam važan za stvaralačku dimenziju čovjeka. Stoga, čini se značajnim tematizirati dogmu sa šire pozicije škole Praxis filozofije, s obzirom na to da su filozofi okupljeni oko bespoštednog kritičkog preispitivanja koje bi dovelo do uspostavljanja humanog društva i razotuđene zajednice, jasno problematizirali i opovrgavali svaku dogmatsku tendenciju reduciranja čovjeka u ključu vulgarnog materijalizma, ekonomicizma ili primata birokratske politike. To se nedvosmisleno može uvidjeti u ključnim djelima praxis-autora, poput Mišljenje revolucije i Marx i marxisti Gaje Petrovića, Praksa, vrijeme, svijet $^{1}$ Milana Kangrge, te Contra dogmaticos, Zašto i Umjetnost i filozofija Danka Grlića.

Danko Grlić - jedan od ključnih mislilaca u okviru zagrebačke filozofije prakse i autor čija su me djela i filozofska pozicija ponukali na ponovni osvrt na problematiku dogmatizma - nedvosmisleno ukazuje na antidogmatsku prirodu filozofije i krucijalnost stvaralačkog u pogledu očovječenja. U cjelokupnom stvaralaštvu, no posebice u djelima Contra dogmaticos i Zašto, Grlić apostro-

Naročito dio koji problematizira moderni pojam prakse, te posebno poglavlja koja se stvaralaštva. - Milan Kangrga, Praksa, vrijetiču odnosa prakse i čovjeka te prakse kao me, svijet, Nolit, Beograd 1984., str. 82-108. 
fira suprostavljenost dogme i filozofije, pri čemu filozofsko mišljenje smatra nužno oprečnim shematiziranju i nekritičkom prihvaćanju jednom utvrđenih istina. ${ }^{2}$ Rad polazi od pretpostavke da je filozofija nužno antidogmatska pa je suprotstavljanje ideologiziranom i politički determiniranom mišljenju nužno za mogućnost stvaralačkog propitivanja kao osnove filozofije.

Stvaralačko se u ovom kontekstu razumije kao neprestano prekoračenje sadašnjeg i danog, kao svjesna usmjerenost prema mijenjanju i propitivanju zbilje, odbacivanju nametnutih i dovršenih istina. To, smatrao je Grlić, podrazumijeva da život treba izjednačiti s umjetničkim djelom, držati do stalnog prekoračenja danih granica i boriti se za otvorenost koja omogućava da se stalno stvara budućnost iz nagona za prekoračenjem, a ne do fiksiranih općih shema koje Grlić izjednačava s dogmom. ${ }^{3}$

Ovim se osvrtom kani apostrofirati da je fundament autentičnog marksizma očovječenje, a ne urušavanje i instrumentizacija čovjeka pa se ovdje ispituje odnos filozofije Karla Marxa i njenih političkih interpretacija te perspektiva revitalizacije marksističke misli s obzirom na današnju tržišnu stvarnost.

Ističući koliko je važno distancirati se od masovnog mišljenja i standardiziranju sklonog djelovanja, rad pledira za stvaralačko koje dano preispituje i tako ističe krucijalnost autonomije čovjeka jer samo korjenito mijenjanje i preoblikovanje, odbacivanje »provjerenih « puteva te odmicanje od (političkog) oportuniteta omogućava uzdizanje čovjeka od knjiškog, apstraktnog, do realnog i djelatnog - istinskog - humaniteta, koji nam je potreban ne samo kao poticaj na permanentnu promjenu, dakle, za novu (revolucionarnu) mogućnost, ${ }^{4}$ nego kao najubojitije opravdanje filozofije u kontekstu potrošačke zbilje.

\section{Grlićev odnos spram Marxova antidogmatizma}

U tekstovima sabranim u djelu Zašto, Grlić tematizira odnos prakse i dogme, objašnjava distinkciju između njih te razmatra dispoziciju prakse. Ističući glavna svojstva prakse, autor se suprotstavlja dogmi, koja prilagođena društvenim danostima suzbija čovjekovu pravu, angažiranu prirodu, a permanentno, stvaralačko preoblikovanje što ga podrazumijeva praksa Grlić stavlja u prvi plan filozofije, čime se ograđuje od filozofiji svojstvene distanciranosti od zbiljnog. Zauzimajući se za stvarnu promjenu svijeta, Grlić potencira ljudsku praksu kao stanoviti način da promjena i napredovanje budu konstituent mišljenja budućnosti. U osnovi takvog djelanja nalazi se humanistički impuls, lajtmotiv svake akcije i njeno odredište. Prema tome, samo korjenito mijenjanje i preoblikovanje, odbacivanje »srednjih « linija, odmicanje od oportuniteta omogućava uzdizanje čovjeka od knjiškog, apstraktnog, do realnog i djelatnog, istinskog humaniteta.

Odnos pojedinac - društvo za Grlića nije jednoznačan. Pojedinca ne treba određivati u striktnim okvirima dominacije personalnog ili kolektivnog jer »čovjekov svijet, jedini istinski svijet, nije naprosto ni dan ni zadan, gotov i završen $\aleph^{5}$ pa bi takva redukcija značila temeljno osporavanje ne tek njegove složenosti nego i same ljudskosti. U tom je smislu, čini se, važno ne inzistirati na tome da društvena bit čovjeka postane njegovo centralno određenje jer čovjek nije odrediv kroz društvo kao takvo, već kroz njegovu mogućnost da ga tvori i stvaralački modificira. U smislu Grlićeve filozofske misli, kroz mogućnosti društva čovjek ispituje domete svojih stvaralačkih potencijala, ali i društvo procjenjuje prema mjeri njegove usklađenosti s ljudskim. To podra- 
zumijeva da istinu ne treba tražiti shodno općim imperativima, nego u kategoriji unutrašnjih samopropitivanja koja nastoje premašiti dani prag istinitosti. Za praxis-filozofa se, prvenstveno na unutrašnjem planu, pomjeraju granice slobode te sve što je omasovljeno ne treba shvatiti drukčije doli potencijalnu opasnost po individualno samonadilaženje. Oponirajući javnom mišljenju, Grlić ne ostaje nedorečen:

»... nikad nas plima općih osjećanja, težnja za uspjehom akcije ili žestina protuakcije ne smije toliko stopiti s bilo kakvim pokretom da bismo smjeli zaboraviti kako ta sama akcija može imati puni smisao tek onda kad u nju unesemo našu vlastitost, našu slobodnu kreaciju, naše samostalno, kritično djelo. $\aleph^{6}$

Pozivajući se na Marxovu skeptičnost spram općeprihvaćenih sudova, Grlić naglašava individualno i kreativno kod Marxa jer to ima dodatnu vrijednost $u$ obrani njegove filozofije koja je posve izopačena u interpretacijama, ${ }^{7} \mathrm{a}$ onda i »potpuno suprotstavljena samim temeljnim, početnim njenim premisama«. ${ }^{8}$ Kada Grlić navodi da je istinsko mišljenje dužno ne samo krčiti nove putove i revidirati postojeće nego da primarno ima biti »samostalna, slobodna, vlastita plovidba u novo « ${ }^{9}$ tvrdi da je stvaralački impuls temelj praktičnom djelovanju. To je ujedno i najvažniji element mišljenja praxis-filozofije i točka u kojoj teoretičari prakse uzdižu marksizam do humanizma - revolucije čovječnosti.

»Praxis-filozofi koji razumijevaju čovjeka kao biće prakse, a praksu kao slobodnu stvaralačku djelatnost nastoje izraziti svojim pojmovima, 'bitne mogućnosti čovjeka', a ne njegovo faktičko 'jest' ili puko 'treba'. Stoga naglašavaju da su upravo bitne mogućnosti čovjeka, njegove potencije za slobodu i stvaralaštvo, osnovna struktura čovjekova bitka. $\ll^{10}$

Marx se ni u kojem smislu ne može tumačiti kao zagovornik primata općeg nad pojedinačnim, države nad pojedincem. Marx je smatrao da individua samo u zajednici s drugima ima mogućnost razviti svoje sposobnosti, dakle, tek u zajednici osobna sloboda postaje moguća - međutim - napominje da je u državi osobna sloboda ograničena jedino na individue razvijene pod okriljem vladajuće klase. ${ }^{11}$ Grlić je upozoravao na to da samo ukoliko postoji istinska komunikacija između personalnog i društvenog, utoliko postoji osnova da se izbjegne okoštalost dogme, u smislu diktata općeg nad individualnim i obratno. ${ }^{12}$ Već je mladi Marx tvrdio da je cilj njegovih spisa kritička analiza

2

Danko Grlić, Zašto, Studentski centar Sveučilišta u Zagrebu, Zagreb 1968., str. 79.

Danko Grlić, Contra dogmaticos, Praxis, Zagreb 1971., str. 25 .

4

Gajo Petrović, Filozofija prakse, Naprijed Nolit, Zagreb - Beograd 1986., str. 70

D. Grlić, Contra dogmaticos, str. 27.

D. Grlić, Zašto, str. 157.

7

Ibid., str. 87.

Ibid.
D. Grlić, Zašto, str. 92.

10

Veselin Golubović, Mogućnost novoga. Vidokrug jugoslavenske filozofije, Zavod za filozofiju Filozofskog fakulteta Sveučilišta u Zagrebu, Zagreb 1990., str. 126.

11

Karl Marks, Fridrih Engels [Karl Marx, Friedrich Engels], Nemačka ideologija: kritika najnovije nemačke filozofije $u$ licu njenih predstavnika Fojerbaha, B. Bauera i Štirnera $i$ nemačkoga socijalizma u njegovim različitim prorocima, prev. Dušan Nedeljković, Kultura, Beograd 1964., str. 81.

12

D. Grlić. Zašto, str. 41. 
stvarnosti te, stoga, nije riječ o uspostavljanju nove, dominantne istine koja će obznaniti nerelevantnost svih drugih.

»Mi onda ne istupamo nasuprot svijetu doktrinarski s novim principom: ovdje je istina, pred njom na koljena! Mi svijetu razvijamo nove principe iz principa svijeta. « ${ }^{13}$

Marx uviđa da čovjeka ne treba stavljati u nove utopijske kalupe, nego ga razvijati do mjere u kojoj će autonomno stvarati okvire za vlastitu egzistenciju. S tim u vezi, Marx i Engels u Njemačkoj ideologiji pišu da će se svestrano ostvarenje individue prestati predstavljati kao ideal tek onda kada sposobnosti individua za stvarni razvitak budu pod kontrolom same individue. ${ }^{14}$ Time Marx i Engels odbacuju apstraktna, pojmovna određenja čovjeka koja ga izmještaju s puta samobitnosti.

Upućujući na otvorenost u temeljnim pitanjima čovjeka i njegovo poštovanje prema intimno ljudskom, Grlić poziva na djelovanje »na zbiljsku, vlastitu, nedirigiranu akciju u ovom našem svijetu u kojem su se tolike moći i totalitarne sile nadvile nad ličnošću da postoji ozbiljna opasnost da je potpuno zgnječe.$^{15}$

\section{Stvaralačka praksa u službi antidogmatizma}

Praxis filozofi, u prvom redu Grlić, Petrović i Kangrga, primjećuju i ističu da angažirana misao i stvaralački impuls nerijetko završe u dogmatskom. Interpretacije Marxa kroz dijamatske pozicije te pozicije na tragu staljinističkog tumačenja, za Petrovića su primjer dogmom determiniranog mišljenja.

Petrović je smatrao da su staljinisti eksplicitnim odbacivanjem mogućnosti filozofskog pojma čovjeka ustvari razradili jedan vulgarni, »ekonomistički« pojam čovjeka, ${ }^{16}$ zanemarujući pritom fundament filozofije - stvaralačko biće prakse. Za filozofiju, posebno jugoslavensku, otklon od takve antihumanističke koncepcije iznimno je važan. Uviđajući krutost i netemeljnost izmještanja čovjeka na mjesto objekta, javlja se potreba borbe za suprotnog, prema čovjeku okrenutog Marxa.

»Nisu svi koji su shvatili Marxa kao humanista bili suglasni u svim pojedinostima, ali mnogi su bili skloni da interpretiraju marksizam kao humanističku »ontologiju-antropologiju« koja se koncentrira na pojam čovjeka kao bića prakse i zahtijeva revolucionarnu promjenu postojećeg društva. $\ll^{17}$

Petrović je Marxa smatrao začetnikom mišljenja revolucije, ${ }^{18}$ a revolucija, po Petrovićevu mišljenju, podrazumijeva stvaranje novih modusa ljudskog bivstvovanja, a to znači da je revolucionarna praksa ne samo neodvojiva od stvaralačkog nego da je stvaralačka bit čovjeka osnova razvoja revolucionarne misli.

»Kao biće prakse čovjek je slobodno i stvaralačko biće, a kao takvo on je i biće revolucije. Revolucija nije neka posebna pojava u povijesti, nego najkoncentriranija forma ljudskog kolektivnog stvaralaštva, forma u kojoj najjasnije dolazi do izražaja stvaralačka priroda čovjeka. $^{19}$

U pismu Josefu Blochu 1890. godine, Engels je priznao da se marksizam vulgarizirao uslijed nemogućnosti da Marx i on temeljitije ukažu na momente koji stoje ravnopravno s ekonomskim te da su pojedini sljedbenici marksizma ekonomskom aspektu pridali veću pozornost, nego što je slučaj u njihovoj filozofiji. ${ }^{20}$ Grlić smatra da se dogmatiziranje marksizma događa upravo zato što se ekonomsko pitanje smatra fundamentalnim, dok se vrši sistemsko zanemarivanje svih onih Marxovih djela koja čovjekov kreativni potencijal 
uzimaju za osnovu društvenog djelovanja. Primjećujući da je dobar dio jugoslavenskih teoretičara stasao na staljinističkoj strukturi mišljenja, Petrovića ne čudi što je instrumentizirano, lagersko tumačenje Marxa dominantno. ${ }^{21}$ Zauzimajući kontrapoziciju koja Marxa tumači kroz mogućnost čovjeka, a ne ekonomije, Grlić ne inzistira na polemiziranju s »teoretskim radnicima« ${ }^{22}$ nego ispitivanjem odnosa umjetnosti i djela Karla Marxa nastoji naći osnovu za stvaralačko tumačenje marksizma.

Slično Grliću i Petroviću, Milan Kangrga razmatra Marxovu poziciju i cijeni da je izuzetno humanistička jer je posrijedi demistificiranje lažnog, nametnutog svijeta, s ciljem promišljanja izgleda za bolji.

»Svojom se filozofijom i naukom u cjelini upravo Marx borio za promjenu takvog i sličnog društvenog stanja, koje proizvodi takve uvjete, u kojima se čovjek za svoje golo preživljavanje srozava na nivo hulje i gomile, na nivo koji čovjeka obezvređuje, obesmišljava, degradira i otuđuje i od same mogućnosti da iz sebe i u sebi izgradi bar minimum čovječnosti. « ${ }^{23}$

Spoznajući da je čovjek angažiran za nešto više, za rastuću čovječnost, filozofi prakse odbacuju dogmatski pristup stvarnosti, upravo time što propituju sadašnjost s pozicija njenog dokidanja. Grlić konstatira da čovjek treba postaviti svoje koordinate tako da mu je ljudska misao važna baš zato što je zbiljska misao, a da njenu kvalitetu mjeri onim što ta misao znači za svijet i za njega samog:

»... on ima ne samo pravo već i dužnost da zatim i vrednuje svijet oko sebe, da ga kritički promatra i da ne dozvoli da bude stavljen u situaciju iz koje uvijek iznova samo njega vrednuju a da on nema nikakvu mogućnost vrednovanja s jedne pozicije koja kadikad mora transcendirati svakidašnjicu baš zato da bi je mogla misaonije i bolje vidjeti. $\ll^{24}$

(Suz)držan na tragu dominantnog, priklonjen ustaljenom, čovjek ostaje neproduktivan i samoograničen, ali i neslobodan. Na taj način, on negira praksu, biva samootuđen i postaje ono što Veselin Golubović naziva "samootuđenim« oblikom slobode. ${ }^{25}$ Suprotstavljajući se svojoj autentičnoj biti, dogma-

13

Karl Marx, Friedrich Engels, »Marxova pisma Rugeu iz 1843. godine«, u: Karl Marx, Friedrich Engels, Dela, sv. 3, Prosveta, Beograd 1972., str. 113-125, ovdje str. 122.

14

K. Marks, F. Engels [K. Marx, F. Engels], $N e$ mačka ideologija, str. 335-336.

15

Ibid.

16

Gajo Petrović, »Humanizam i revolucija«, Praxis (1970), br. 4, str. 634-644, ovdje str. 635.

17

Ibid.

18

Gajo Petrović, Marx i marxisti, Naprijed Nolit, Zagreb - Beograd 1986., str. 30.

19

Gajo Petrović, Mišljenje revolucije, Naprijed, Zagreb 1978., str. 76.
20

Karl Marks, Fridrih Engels [Karl Marx, Friedrich Engels], $O$ književnosti $i$ umetnosti: izbor, prev. Jovan Popović, Rad, Beograd 1962., str. 15.

21

D. Grlić, Zašto, str. 82.

22

Ibid., str. 83 .

23

Milan Kangrga, Nacionalizam ili demokracija, Izdavačka knjižarnica Zorana Stojanovića, Novi Sad 2002., str. 213.

24

Ibid., str. 127

25

Ibid. 
tičan čovjek ne vjeruje u povijesni progres i biva ketman, tražena uloga $\mathrm{u}$ nametnutim konstantama, postaje laž u koju je ukalupljen, prihvaća misao samo ako ne propagira promjenu, a svaku slobodnu, kako primjećuje Grlić, kani pretvoriti $\mathrm{u}$ »muzejsku relikviju«. ${ }^{26}$

Za Grlića nema dileme da je sloboda preduvjet realnog humaniteta, ali je ne prepoznaje samo u nedogmatskom mišljenju nego, primarno, u nezavisnom djelovanju i stvaralačkom aktivitetu čiji je glavni teren revolucija. ${ }^{27}$ Premda kod Grlića revolucija nije središnji pojam i služi kao potpora stvaralačkoj slobodi, on revoluciju intenzivno promišlja kroz zahtjev za umjetničkom promjenom svijeta. Na tom tragu, Ozren Žunec primjećuje da se u mišljenju Danka Grlića bitak razumije upravo iz horizonta umjetnosti kao revolucije pa se iskustvo umjetnosti podjednako zadobiva iz mišljenja revolucije, kao što se i revolucija naslućuje na prostoru umjetničkog. ${ }^{28}$ Proces revolucioniranja stvaralački oblikuje i gradi novi humanitet jer »nužnost sinteze čovjeka i njegova svijeta proizlazi prije svega iz zahtjeva za totalnom izmjenom $\ll{ }^{29}$

Grlić smatra da je zahtjev za umjetničkim u čovjeku bitnost Marxovog antidogmatizma. No, i na primjeru odnosa prema religiji može se bliže razumjeti Marxova antidogmatska pozicioniranost. Naime, Marx piše da je (politička) emancipacija moguća samo pod uvjetom emancipacije od religije te nedvojbeno pledira za oslobođenje od predrasuda koje ljude međusobno udaljavaju time što ih smještaju u partikularne i proturječne okvire. ${ }^{30}$ Osporavajući religiju i neupitno vjerovanje u ljudsku podčinjenost, on se suprotstavlja svakoj općosti i posrednom oslobođenju pa se čini da u nepreduvjerenosti leži razlika između umjetničke i religiozne pozicije, što Grlić dodatno podupire mišlju da "sve podliježe kritici, sve treba mijenjati, nitko nema prava na neprikosnovenost, ničija misao nije sakrosanktna« ${ }^{31} \mathrm{Kad}$ Marx tvrdi da je razlika između kršćana i Židova u drukčijim razvojnim putevima ljudskog duha i inzistira na tome da su posrijedi »od povijesti napuštene zmijske košuljice $\ll,{ }^{32}$ govori u prilog čovjeku kojega treba percipirati kao zmiju što mijenja košuljicu, zauzima se za onoga koji odbacuje i kritički preispituje - drži do toga da je čovjek taj o kome zavisi, a ne onaj koji je zavisan.

Kritikom religije, Marx odbacuje svaku suverenost koja se čovjeku nameće izvana. Ukidanje religije podrazumijeva uzdizanje iznad sistema, suprotstavljanje svemu što čovjeka degradira i svodi na sporadičnu ulogu. Kao što je sistem utemeljen na pokornosti i ukidanju slobode represivan sistem koji i sam mora biti ukinut, tako i država temeljena na prividnim slobodama u svojoj proturječnosti ograničava i minimalizira čovjekove stvaralačke sposobnosti i onemogućava samooslobođenje i humanizaciju. Tako suprotstavljena humanizmu, država postoji nauštrb čovjeka, koji tek kada se društveno emancipira preuzima ulogu aktivnog subjekta jer razumije da je on taj koji konstruira svaki sistem.

Ukoliko se praktičnoj, empirijskoj biti subjektivne konzumerističke svijesti dá ljudski oblik, utoliko gubi svoj predmet pa se - siguran je Marx - ukida i konflikt individualno-čulne egzistencije s rodnom egzistencijom čovjeka. ${ }^{33}$ Marx poistovjećuje židovstvo s filistarskim duhom te, iako nije posrijedi prijekor Židovima, nego trgovačkom karakteru društva, društvenu emancipaciju misli kao emancipaciju društva od židovstva. ${ }^{34}$ Premda se čini da je kritika usmjerena na religiju i praksu Židova, »židovsko pitanje« je upitanost nad religijom uopće - kritika židovstva svake religije. Suprotstavljanje religiji ukazuje na dimenziju čovjeka koja se može realizirati samo kroz njegovu 
samosvjesnost. Ozbiljenje filozofije koje Marx zahtijeva u cilju unapređenja stvarnosti i istinskog dovršenja i prekoračenja misaonog, ukazuje na uvjetovanost društvenih okolnosti čovjekom, a ne obrnuto.

Ukazujući na procese koji čovjeka udaljavaju od njegove biti, on potiče na samorazmatranje, koje i sam uzima za određujuće svojstvo (neotuđenog) čovjeka. Čovjek nije slobodan, ali to ne implicira da treba prihvatiti deficit slobode kao usud.

»Mi svijetu samo pokazujemo zašto se on zapravo bori, a svijest je takva stvar do koje on mora doći, makar to i ne htio. Reforma svijesti sastoji se samo u tome da dopustimo svijetu upoznati svoju svijest, da ga probudimo iz sna o samome sebi, da mu objasnimo njegovo vlastito djelovanje $[\ldots] . \ll^{35}$

Grlić tumači Marxa dominantno kroz njegov humanistički aspekt jer se središnja dimenzija ovog filozofa ukazuje ne kroz ekonomski, nego a priori ljudski okvir. Stav da bi trebalo otpočeti živjeti umjetnički krucijalan je stav na kojem Grlić gradi filozofiju slobodnog društva koje mora nastati na ruševinama dogmatiziranog intimiteta. U Contra dogmaticos, Grlić piše:

»Da se sam život konstituira kao umjetničko djelo, to jest život otvoren, bez ograda i okvira, kao stalno stvaranje a ne kao vrtnja u krugu, jalova kontemplacija, korekcija promašenog ili nemoć i strah pred budućim, nikakva šablona životarenja, već lomljenje svega što priječi spontanost, nikakav, dakle palijativ ili nadomjestak života, već život sam u svojoj punini - to je jedna od teza koju Marx ima pred očima, a koju smatram bitnom. $\ll^{36}$

Filozofija potaknuta zbiljom vjeruje u proces mijenjanja i ljudsku praksu izjednačenu s filozofijom, te humanističko propitivanje djelatnog aspekta filozofije podrazumijeva da temeljna pitanja čovjeka ne mogu ostati samo u okvirima kontemplativnog.

Koncentriran na stvaralačko revolucioniranje, Grlić drži do toga da je umjetnost presudna za potresanja starog i konstituiranje novog svijeta koji će označiti početak radikalnog događanja čovjeka. Stvaralačka moć i s njom povezana revolucionarna potencija točke su koje ovaj autor prepoznaje kao stativ marksističke misli.

»Marxove osnovne intencije o očovječenju čovjeka, o revalorizaciji istinskih ljudskih mogućnosti, o ozbiljenju filozofije, dakle i onog stvaralačkog u jednoj novoj stvarnosti i ljudskoj atmosferi, o afirmaciji one zamisli koja ljude lišava nužne životinjske borbe za materijalno tavorenje, o prelasku iz animalnog carstva nužnosti u čovjekovo carstvo slobode [...] mnogo su presudnije

26

D. Grlić, Zašto, str. 91.

27

Ibid., str. 31.

28

Ozren Žunec, »Revolucija i igra«, u: Gajo Petrović (ur.), Umjetnost i revolucija. Spomenica Danku Grliću, Naprijed, Zagreb 1989., str. 51-60, ovdje str. 52 .

29

D. Grlić, Zašto, str. 25.

30

Karl Marks [Karl Marx], O jevrejskom pita$n j u$, prev. Milorad V. Simić, Arhiv za pravne i društvene nauke, Beograd 1952., str. 3-4.
31

D. Grlić, Zašto, str. 80.

32

K. Marks [K. Marx], O jevrejskom pitanju, str. 4.

33

Ibid., str. 28.

34

Ibid.

35

K. Marx, F. Engels, »Marxova pisma Rugeu iz 1843. godine «, str. 122 .

36

D. Grlić, Contra dogmaticos, str. 25. 
za marksistički smisao određenja umjetničkog djela no što su sve Marxove izjave o svim tim djelima $[\ldots] \cdot \ll^{37}$

Na prigovore antimarksista da Marx nije stvorio estetički sistem te da nije moguće govoriti o osobitom marksističkom odnosu spram umjetnosti, Grlić odgovara da je Marxu u potpunosti stran estetski pristup umjetnosti karakterističan za cjelokupnu povijest te discipline ${ }^{38}$ te da samo površno poznavanje i dogmatizmom opterećeno interpretiranje njegove filozofije može zaključiti o neumjetničkoj nastrojenosti njegove, kako se misli, isključivo prema praksi usmjerene misli.

U vezi s krivim tumačenjem marksističkog odnosa spram umjetnosti, Grlić je istaknuo tri dominantne predrasude karakteristične za ovaj pristup. Prva se odnosi na predrasudno shvaćanje odnosa između umjetnosti i ideologije, druga se odnosi na potenciranje teorije odraza, a treća se odnosi na stav da umjetnost iskazuje socijalnu sliku društva. ${ }^{39}$

Kada je posrijedi prvonavedena predrasuda, koja potencira ideološki karakter umjetnosti, Grlić je smatrao da je umjetnost kao »najljudskije ispoljavanje ljudskog, nešto drugo no sve one otuđene manifestacije duha što se zovu nadgradnja $\ll^{40}$ te se u svojoj biti neprestano odupire izazovima da bude svedena na određeni sadržaj, a posebno onaj koji služi vladajućoj ideologiji. Ukoliko se uzme da je osnovna karakteristika umjetnosti pružati otpor, propitivati i osporavati svako instrumentiziranje u korist izvanumjetničkog, utoliko je njeno svođenje na ideološko služenje posve neopravdano i bitno manjkavo. Budući nepomirljiva s danim, umjetnost uvijek na temelju priložene stvarnosti gradi vlastiti, sasvim novi realitet, koji onda može po vlastitom zahtjevu za promjenom preobražavati društvenu stvarnost. Ona je, dakle, dominantno usmjerena na prevladavanje i preobrazbu stvarnosti pa Grlić s pravom ističe da je ona bitno revolucionarna, ${ }^{41}$ što samo dodatno ukazuje na to da ona nije podesan materijal za političko oblikovanje, iako se katkad i pojedinim deklariranim marksistima na temelju pogrešnog interpretiranja Marxa tako nešto može učiniti.

Teorija odraza predstavlja drugi neosnovani pokušaj da se umjetnost degradira i da se marksizmu neosnovano pripiše dimenzija umjetnosti koja nije autentično ni umjetnička, ni marksistička. Praxis-autor objašnjava da je zastarjelost ove teorije neupitna, ali da je toliko ukorijenjena u određenim, uglavnom kvazimarksističkim teorijama da je, čini se, stalno treba ponovo osporavati.

»Ona je tipični ideološki, građanskim horizontom određeni pokušaj da se fiksira i utemelji u toj fiksnoj statičnosti današnji svijet i da se činjenično utvrđenim fakticitetom zagarantira nepromjenjivost tog objektivnog svijeta koji se zatim može - manje ili više subjektivno - samo odražavati, zrcaliti. $\aleph^{42}$

Sasvim je jasno da ova teorija reducira umjetnost, objašnjava je kroz dostupno, fiksirano i izvanjsko, što u konačnici previđa unutrašnje bogatstvo i humanistički potencijal umjetničkog djelovanja. Zato Grlić nedvosmisleno tvrdi da tek rušenjem teorije odraza umjetnost pronalazi suštinsku snagu, a to ne treba shvatiti drugačije, nego kao dodatno koncentriranje njene revolucionarne moći. ${ }^{43}$

Nadalje, a u vezi sa zabludom koja drži do toga da umjetnost ukazuje na socijalno stanje društva, Grlić je primijetio da ovakvo viđenje podcjenjuje marksizam i svodi ga na reakciju, društveni komentar, da skučava njegov filozofski horizont ${ }^{44}$ te zanemaruje mogućnost dubljeg marksističkog uvida u umjetnost, s obzirom na to da se ona ne smatra autonomnim, od sociološ- 
kog realiteta nezavisnim područjem. Upravo iz tog razloga, Grlić ističe da je umjetnost privatno umjetničko viđenje svijeta, ${ }^{45}$ što dalje implicira da se umjetnički smisao ne može temeljiti na društvenim analizama, nego jedino na pojedincu i njegovim humanističkim vrijednostima.

Bitno je napomenuti da tri pogrešne konkluzije, koje se tiču međuodnosa marksizma i umjetnosti, govore o jednoj degradiranoj estetici koja bi, u najboljem slučaju, mogla svijet samo prikazati, ne dajući mu novu dimenziju i ne gradeći od njega novi entitet. U svjetlu takve estetike, marksizam postaje uslužna filozofija bez autentičnijeg sadržaja od zbilje i bez veće uloge u mijenjanju njenog supstrata. Vodeći računa o umjetnosti i njenoj dubokoj povezanosti s očovječenjem, Grlić ne izvodi samo generalne zaključke iz danih teorija, nego polemizira s njihovom utemeljenošću i nudi novi uvid u estetske sfere, baveći se ne samo teoretiziranjem o umjetnosti nego i pojedinim umjetnostima. Prema tome, kako bi dodatno argumentirao i ukazao na značaj stvaralačkog u pogledu humanizacije društva, Grlić u četvrtom svesku Estetike tematizira odnos filozofije i posebnih umjetnosti poput teatra, muzike, arhitekture i literature. Svi ovi oblici umjetničkog ispoljavanja mogu doprinijeti nadilaženju jaza između društva i umjetnosti, a to znači pojedinca i s njim neusklađenog vanjskog svijeta, što Grlić posebno apostrofira zahtjevom za uzdizanje zbilje na rang »životno umjetničkog «. ${ }^{46}$ To podrazumijeva da umjetničko stvaralaštvo može biti adekvatan model po kojem će se oblikovati međuljudski odnosi i unaprijediti kakokracija, no ne u smislu nametanja pojedinih umjetnosti društvu, nego uspostavljanjem temeljnog umjetničkog, tj. stvaralačkog principa za samu osnovu društvene egzistencije, posebno ako se prihvati da je čovjek doista čovjek kada se ne otuđuje od svoje stvaralačke biti, kada je otvoren prema budućnosti i kada realizirajući svoje povijesno dane ljudske mogućnosti stvara nove, više. ${ }^{47}$

Sreten Petrović istaknuo je da Danko Grlić, iako duboko naslonjen na filozofiju Karla Marxa - što, podvlači, nije uobičajeno među estetičarima njegova ugleda - ne robuje recidivima dogmatizma koji je karakterističan za teorijska promišljanja umjetnosti iz prve polovice dvadesetog stoljeća. ${ }^{48}$ Nedvosmisleno ostajući pri Marxovu određenju čovjeka kao idealnog, subjektivnog totaliteta društva, Grlić ne negira bitnost društvenih odnosa, ali ih promatra s obzirom na čovjeka kao kriterij. Suglasna s ovakvim viđenjem, Zagorka Golubović ističe da čovjek kao totalitet nije relevantna kategorija samo za

37

Danko Grlić, Estetika, sv. 4, S onu stranu estetike, Naprijed, Zagreb 1979., str. 355.

38

Ibid., str. 276.

39

Ibid., str. 277.

40

Ibid.

41

Ibid., str. 280.

42

Ibid., str. 281

43

Ibid., str. 283.

\section{4}

Ibid.

45

Ibid., str. 285.

46

Ibid., str. 289.

47

G. Petrović, Filozofija prakse, str. 35.

48

Sreten Petrović, »Umetnost u funkciji revolucionarnog čina«, u: G. Petrović, Umjetnost $i$ revolucija, str. 60-76, ovdje str. 61 . 
pojedinaca nego i za društvo jer se totalitet društva mora razvijati tako da osigura realizaciju totaliteta čovjeka. ${ }^{49}$ Ukoliko ne djeluje prema spomenutom totalitetu, utoliko se čovjek otuđuje od svoje prirode i miri s ograničenjima povijesne uvjetovanosti u koje zapada.

Grlić je naglasio da se u korist ljudskog valja suprotstaviti svim teorijama koje propagiraju da je čovjek u izvjesnom smislu bačen u svijet »u kojem se javlja kao osuđen na svoju od čovjeka nezavisnu sudbu, isključivo predodređenu principima nekog višeg nepromjenljivog svijeta vrednota ${ }^{50}$ Dakle, Grlić s pozicija slobode negira mogućnost idejne i materijalne determiniranosti čovjeka, čime, čini se, nedvosmisleno brani čovječnost od pasivne podređenosti i apriorne autodestrukcije. Gajo Petrović ide korak dalje i slobodu izjednačava sa samim čovjekom:

»Nesloboda nije smrtna opasnost, nesloboda je smrt čovjeka. Postajući neslobodan, čovjek prestaje biti čovjek. «1 $^{51}$

Dogmatizam implicira da sistem porobljava čovjeka i osuđuje ga na poželjan način mišljenja i djelovanja koji je stran elementarnim ljudskim pretpostavkama komunikacije ${ }^{52}$ pa je posrijedi kretanje u okvirima nametnute »slobode« i prividnog izbora. Dostizanje novih mogućnosti čovjeka podrazumijeva aktivan, umjetnički odnos spram zbilje jer se stvaralaštvom, kako to precizira Zagorka Golubović, »dokazuje širi antropološki smisao ljudske egzistencije i ljudske prakse, koja se nigdje i nikada ne svodi samo na borbu za opstanak, već potvrđuje težnju da se život ljudski osmisli«. ${ }^{53}$ Iz toga razloga, čovjek ne može biti podređen strukturi koja ga premašuje i stavlja u nedjelatan i zavisan položaj jer praksa svojom biti proturječi shematiziranju. No, djelovanje nije važno samo s obzirom na cilj, sugerira Grlić, jer ne postoje apriorne vrijednosti koje čovjek dostiže akcijom, nego je bit čovječnosti čovjeka u samom djelovanju. ${ }^{54}$ To znači da praksa u sebi nosi i cilj i sredstvo, da se ispoljavanjem dinamične biti čovjeka ujedno ispunjava zahtjev njegove prirode, ali i premašuju granice koje nam postavlja datost.

Stoga, značaj praxis-filozofije ogleda se ponajviše u njihovom otvorenom, »neslužbenom « i stvaralačkom odnosu spram marksizma, kojeg propituju da bi ga ojačali očovječenjem, a ne da bi ga instrumentizirali. Da bi marksizam ostao na autonomnim pozicijama stvaralačkog humanizma, mora biti otvoren i samokritičan, na što upućuje Rudi Supek kada piše koliko je nužna

»... rehabilitacija otvorenosti samog marksizma, njegove spremnosti da se uhvati u koštac sa svim novim problemima koji se pojavljuju u toku društvenog razvoja, njegova smjela konfrontacija sa svim idejnim i teorijskim shvaćanjima koja idu drugim putovima. ${ }^{55}$

Prema tome, marksizam se uvijek mora opetovano promišljati i to prvenstveno u cilju da ne zapadne u samonametnute okvire, zakonitosti i povijesne postulatnosti koji ograničavaju čovjeka, kakav je slučaj sa svakom dogmatskom, manje ili više svjesno autocenzuriranom interpretacijom Marxa.

Grlić je primijetio paradoks u tome da se tražila jednakost u mišljenju, a da se istovremeno nije problematizirala nejednakost klasnog položaja, ${ }^{56}$ što jasno govori o jednodimenzionalnoj perspektivi centara moći koji održavaju moralizirajući diskurs, a previđaju stvarne probleme čovjeka i društvenog razvoja. Nametanje takvog, odozgo usmjerenog marksizma, za ovog je autora potpuno pogrešno. 
»Tako se zapravo i marksizam uopće - nošen od samog početka esencijalno humanim impulsom - interpretiran na području kulture kao ekonomizam - pretvara u direktni antihumanizam, u kojem su i ljudi mjereni mjerilom stvari i koristonosnom upotrebljivošću. ¿77 $^{57}$

Grlić je naglasio da je Marx potpuno suprotan takvom determinizmu i ističe da je kod Marxa upravo najvrijednija usmjerenost na kreativno oslobađanje čovjeka, kako bi on, kao autonomna osoba, bio u poziciji zauzeti nonkonformistički stav prema onom što ga okružuje i time izraziti svoj stav potpuno nezavisno od toga kakav je vanjski odnos prema predmetu njenoga mišljenja. ${ }^{58}$

\section{Zaključak}

Suprotstavljajući se dogmatskim tendencijama koje opstruiraju čovjekovu kreativnu bit, Grlić je pisao o primatu umjetničke komponente marksizma i njenom značaju. Promišljajući stvaralačku komponentu marksizma, odbacio je jednostrano ekonomsko-determinističko stajalište, ukazujući na njegovu nečovječnu prirodu. Grlić je inzistirao na tome da je stvaralaštvo uvijek vid protesta protiv postojećeg, želja za vlastitim samoostvarenjem kroz promišljanje novog, a s obzirom na to da je marksizam utemeljen na takvom kreativnom deshematiziranju, on ne može biti drugo do filozofija oslobođenja. Marksizam je, dakle, suprotstavljen pukim subjektivističkim, nefundiranim impresijama što se neodgovorno razbacuju dojmovima koji nemaju zbiljsku zasnovanost i svakim fiksnim skelama utvrđenih ideoloških koordinata koje pretendiraju da nikada ne budu srušene..$^{59}$

Istinska, nedirigirana umjetnost nameće pitanje promjene, čime demistificira i demantira status quo. Revolucija - akcija neobuzdanog mišljenja koja potiskuje stare vrijednosti - ima umjetnički karakter jer se novostvorenom vrijednošću ne obustavlja, nego konstituira novi povod za buduće revolucionarno djelovanje. Umjetnost i revolucija oslobađaju čovjeka prošlog i to rasterećenje od pređašnjeg, napuštanje zarad nove mogućnosti napuštanja, nove razine osvajanja čovjeka, određuje mjeru spremnosti da se prihvati sloboda kao vitalna potreba.

49

Zagorka Pešić-Golubović, »Mesto antropologije u Marxovoj koncepciji istorijskog materijalizma«, Praxis (1967), br. 3, str. 305-313, ovdje str. 312 .

50

Danko Grlić, »Pitanja o slobodi«, u: Miloš Stambolić (ur.), Čovek danas, Nolit, Beograd 1964., str. 77-93, str. 80.

51

Gajo Petrović, »Čovjek i sloboda«, u: M. Stambolić (ur.), Čovek danas, str. 33-55, ovdje str. 38 .

52

D. Grlić, Zašto, str. 125.

53

Zagorka Golubović, Čovek i njegov svet $u$ antropološkoj perspektivi, Plato, Beograd 2006., str. 9.
54

D. Grlić, Zašto, str. 132.

55

Rudi Supek, »Čemu, uostalom, sad još i ovaj marksizam«, Praxis (1972), br. 3-4, str. 327338, ovdje str. 334.

56

D. Grlić, Zašto, str. 294.

57

Ibid., str. 151.

58

D. Grlić, Filozofija $i$ umjetnost, Naprijed Nolit, Zagreb - Beograd 1988., str. 150.

59

Ibid., str. 159. 
Svako djelovanje na liniji humanizma nova je pukotina na zdanju dogmatizma, kao što je i svako umjetničko djelo mala revolucija u korist istinskih vrijednosti. Perspektiva osvajanja slobode neodvojiva je, dakle, od partikularne odgovornosti spram općih vrijednosti pa se može promatrati i kao osobni revolucionarni čin u cilju reintegriranja stvaralačkog čovjeka. Drugim riječima, da bi radikalno transformirao, čovjek mora radikalno stvarati i preispitivati. Nije li, stoga, umjetnost revolucija koja traje?

Grlićev afirmativan stav prema umjetnosti, ali i spram revolucije - koju smatra koliko imanentnim elementom ljudskog, toliko i temeljnim elementom umjetnosti - dovodi u pitanje svaki pristup koji uniformno odbacuje sve ono što uzmiče standardnom i sistemski poželjnom. Braneći stvaralačku potku marksističke filozofije, on poziva na reformiranje kvazimarksističkog pristupa umjetnosti, naglašavajući pritom da se istodobno:

»... ne samo ne negira, nego, štoviše, afirmira izvorno revolucionarno, dakle marksističko osmišljavanje upravo toga novoga u umjetnosti, koje u ovom trenutku svjetske kulturne povijesti ima svoje izuzetno i doista epohalno značenje. $\ll^{60}$

Vjerujući da »dogmatizirana negacija dogmatizma ${ }^{61}{ }^{6}$ ne dospijeva dalje od puke demagogije, Grlić uviđa da je proturječnost između razvoja sistema i autonomije umjetnosti kompleksan problem koji ne može biti jednoznačno definiran. Razvoj društva trebalo bi voditi prema što većem oslobađanju, međutim, uslijed nastojanja da se proces »oslobađanja« uspostavi i prati odozgo te time stavi pod kontrolu onih koji oslobađanje najbolje procjenjuju, mjere i po potrebi reduciraju, društvo se sve više udaljava od početne pretpostavke, čime se dolazi do paradoksa slobode - u navodnom cilju da se potakne, sloboda se ograničava, a država totalitarizira u naporu da bude determinanta napretka društva.

Ipak, Grlić je jasan pri odbrani stvaralačkog imperativa - neophodnog uvjeta svakog djelovanja - ali i kod uspostavljanja distinkcije između one vrste (dogmatskog) marksizma koja se nameće kao kompetentna da ocjenjuje svaki drugi i onog istinskog marksizma - Marxove filozofije - koji procjenjuje s obzirom na stvaralačku potenciju i humanističku perspektivu. Imajući u vidu potpuno postvarenje čovjeka, Grlić piše o oslobođenju i nadilaženju njegove podčinjenosti. Oslanjajući se na Marxovo vjerovanje u prijelaz prema pravoj povijesti čovječanstva, Grlić nema dilemu da je umjetničko mijenjanje fundament humanističkog obrata:

»Umjetnost se više ne približava i ne prilagođava svijetu, ona se više ne snalazi u jednoj njoj bitno suprotstavljenoj 'gruboj' danosti, već svijet počinje živjeti u umjetnosti. Humano tek postaje stvarno, a stvarno humano. $\ll^{62}$

Dakle, za Grlića je umjetnost jedan od najrelevantnijih kriterija za ispitivanje mogućnosti društvenog preobražaja pa, ukazujući na značaj potrebe za umjetnošću koja umnogome korespondira s revolucionarnom prirodom čovjeka, Grlić apostrofira umjetničku prirodu promjene. To implicira da je za samoostvarenje nužno iznalaženje vlastitog puta:

»Rušiti znači često puta mnogo više ukazati na novi put, znači zapravo više graditi no popravljati, krpati, uljepšavati utabane staze čiji su se temelji dobrano izlizali. « ${ }^{63}$

Slijedeći ovu misao, put k očovječenom čovjeku podrazumijeva ujedno i premašivanje i ponovno uspostavljanje - razaranje nečovječnog i sazdavanje humanog. 


\title{
Slađana Kavarić Mandić \\ Dogma and Creativity: A Contribution to the Evaluation of Grlić's Critique of Dogmatism
}

\begin{abstract}
The paper deals with basic characteristics of dogmatic thinking, taking into consideration especially the relation towards the creative essence of the human being. Discussing the development of human being and its (self)perception in the conditions of desirable uniformity and limited freedom, the paper strives to point at the inevitability of continuous overcoming of given possibility and point out the meaning of candid, antidogmatic practices aimed at making the humanistic philosophy come to be. Referring to the basic assumptions of Danko Grlic's philosophy, the work examines the implications of Marx's political instrumentalisation, draws attention to the one-dimensionality of dogmatic thinking and emphasises the antidogmatic nature of original Marxism.
\end{abstract}

Keywords

Danko Grlić, Karl Marx, Marxism, dogma, creativity, humanism

60

D. Grlić, Filozofija i umjetnost, str. 219.

61

Grlić napominje da pri analizi jednoobraznog načina mišljenja postoji opasnost od zalaženja u nepotrebna uopćavanja i frazerstva, koja karakteriziraju upravo kritizirano, dogmatsko mišljenje. Takve tendencije značile bi kritiku dogmatizma s njemu svojstvene pozicije zatvorenosti te je, prije, posrijedi zapadanje u dublji dogmatizam, negoli konstruktivna, stvaralačka kritika. - Ibid., str. 220.
62

Danko Grlić, Umjetnost i filozofija, Mladost, Zagreb 1965., str. 30.

63

D. Grlić, Contra dogmaticos, str. 31. 